\title{
Responses of Coronary Vessels to Adrenergic Stimuli
}

\author{
Donald R. McRaven, Allyn L. Mark, Francois M. Abboud, and \\ Howard E. MAYER \\ From the Cardiovascular Division, Department of Internal Medicine, \\ University of Iowa College of Medicine, and the Veterans Administration \\ Hospital, Iowa City, Iowa 52240
}

A B S T R A C T Coronary responses to adrenergic stimuli were determined in the intact beating heart before and after administration of practolol, 4-(2-hydroxy-3isopropylaminoproproxy) acetanilide, which in low doses blocks myocardial but not vascular beta receptors. The left circumflex coronary artery of dogs was perfused with arterial blood at constant flow, and coronary perfusion pressure was measured.

Before practolol, intracoronary injections of isoproterenol and norepinephrine and electrical stimulation of left cardiac sympathetic nerves caused reductions in perfusion pressure or vasodilatation associated with increases in left ventricular $\mathrm{dp} / \mathrm{dt}$, heart rate, and systolic pressure.

After practolol, the coronary vasodilator response to isoproterenol was reduced by about $30 \%$ and occurred without significant changes in $\mathrm{dp} / \mathrm{dt}$, heart rate, and pressures. The addition of propranolol blocked completely the coronary responses to isoproterenol. Vascular responses to isoproterenol in the paw were not altered by practolol.

Practolol antagonized the increases in $\mathrm{dp} / \mathrm{dt}$, heart rate, and systolic pressure and reversed coronary responses to norepinephrine and nerve stimulation from dilatation to constriction. The constriction, in turn, was reduced or reversed by phentolamine, an alpha receptor antagonist. Propranolol did not augment the constriction seen in response to norepinephrine and nerve stimulation after practolol.

These results indicate that the coronary vasodilator action of norepinephrine and sympathetic nerve stimulation is indirect and caused by stimulation of myocardial

This work was presented in part at the National Meeting of the American Federation for Clinical Research, Atlantic City, May 2, 1970. A preliminary report has appeared in abstract form (1).

Dr. McRaven's present address is 13875 Forest Grove Road, Brookfield, Wis. 53005.

Received for publication 22 September 1970 and in revised form 13 November 1970. beta receptors. The direct effect of these two stimuli on coronary vessels is minimal and is mediated through stimulation of alpha (vasoconstrictor) receptors. In contrast, the coronary vasodilator response to isoproterenol is both direct and indirect, resulting from stimulation of vascular and myocardial beta receptors; the direct vascular effect predominated in this study.

\section{INTRODUCTION}

Adrenergic stimuli influence coronary vascular resistance directly through effects on coronary vessels and indirectly through myocardial effects (2). Previous attempts to determine the direct vascular effects by eliminating the myocardial component. included studies of coronary responses in fibrillating or arrested hearts (3-5) or in isolated vessels (6). Until recently, it has been difficult to separate direct and indirect effects in the beating heart because drugs which blocked beta receptors in the myocardium also antagonized beta receptors in coronary vessels.

In these experiments, coronary vascular responses to adrenergic stimuli were studied in the intact beating heart before and after administration of practolol, a new drug which in low doses antagonizes selectively myocardial, but not vascular, beta receptors (7).

\section{METHODS}

Mongrel dogs weighing 19-25 kg were anesthetized with chloralose, $50 \mathrm{mg} / \mathrm{kg}$, and urethane, $500 \mathrm{mg} / \mathrm{kg}$. The animals were treated with decamethonium bromide, $0.3 \mathrm{mg} / \mathrm{kg}$, and ventilated artificially with room air and supplemental oxygen. Through a left thoracotomy, a segment of the left circumflex coronary artery was cannulated and perfused at constant flow $(40-60 \mathrm{ml} / \mathrm{min})$ with heparinized blood from a femoral artery using a peristaltic pump (Fig. 1). Initially, flow rate was adjusted so that coronary perfusion pressure approximated systemic arterial pressure; this rate then was maintained for the rest of the experiment. With flow constant, changes in perfusion pressure reflected changes in coronary vascular resistance. Perfusion pressure fell abruptly to $10-20 \mathrm{~mm} \mathrm{Hg}$ when the perfusion pump was stopped, 


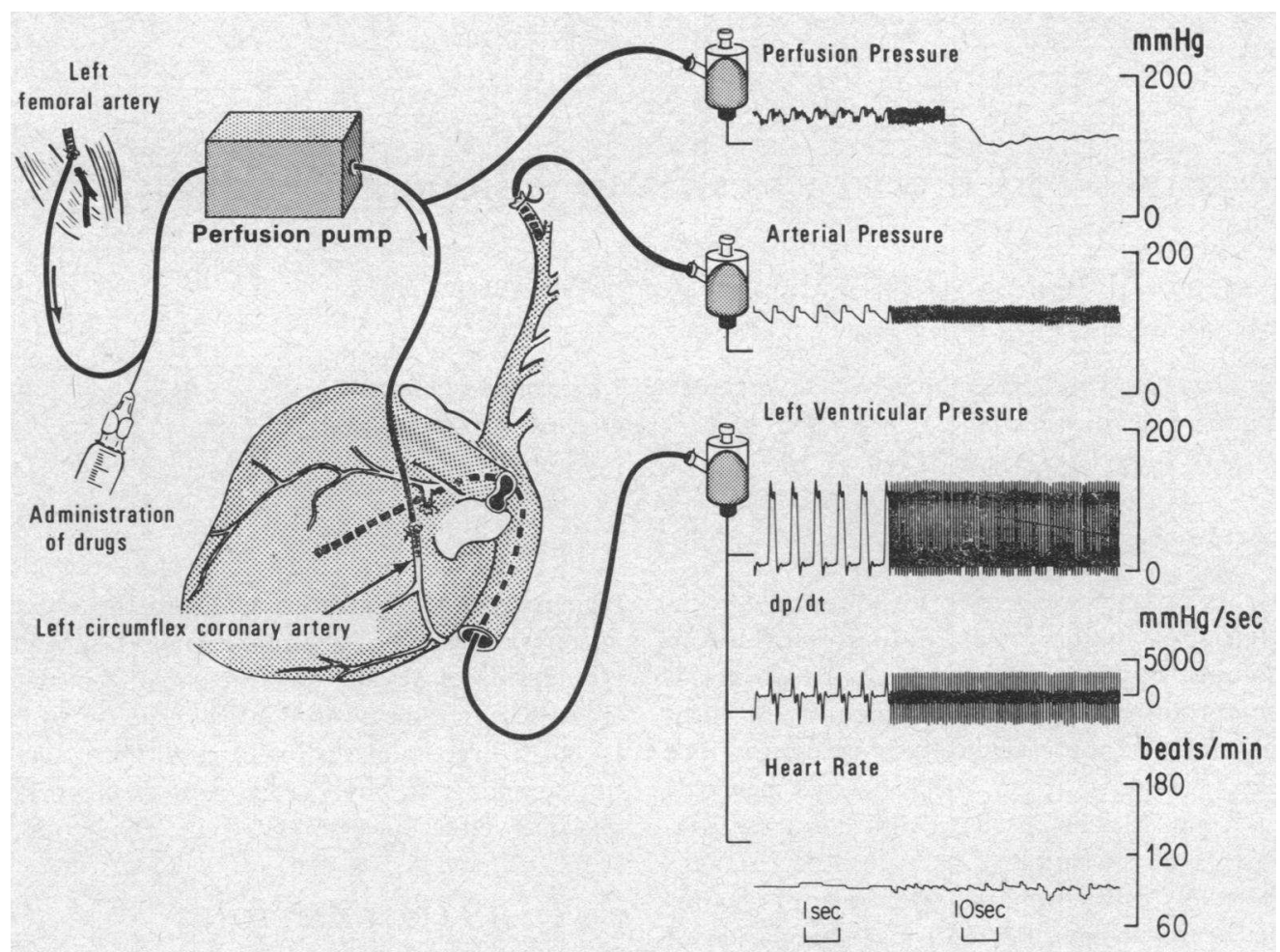

FIGURE 1 A dilator response, represented by a fall in perfusion pressure of left circumflex coronary artery, is shown.

and there was essentially no back flow of blood from the distal end of the cut vessel at the time of cannulation, which suggests that there was little or no collateral flow. Responses to stimuli were taken as peak changes in perfusion pressure. In addition to perfusion pressure, aortic and left ventricular pressures, left ventricular $\mathrm{dp} / \mathrm{dt}$ (LV $\mathrm{dp} / \mathrm{dt}$ ), and heart rate were recorded. $\mathrm{LV} \mathrm{dp} / \mathrm{dt}$ was obtained using a No. 7F cardiac catheter, a Statham P $23 \mathrm{Db}$ pressure transducer, and an RC differentiating circuit with a time constant of $0.5 \mathrm{msec}$. Beat-to-beat changes in rate were measured using a cardiotachometer.

Drugs used as agonists were isoproterenol hydrochloride, $l$-norepinephrine bitartrate, glyceryltrinitrate, and val ${ }^{5}$-angiotensin-II amide. Fresh solutions were prepared for each experiment using appropriate dilutions of stock solutions in 5\% dextrose and water. The agonists were injected into the perfusion tubing upstream from the pump in volumes of $0.02-0.2 \mathrm{ml}$; injections of these volumes of dextrose solution alone had no effect. The left cardiac nerves were sectioned close to the left stellate ganglion and stimulated at $10 \mathrm{v}$ with cycles of $4 \mathrm{msec}$ duration at variable frequency. Antagonists used in the study were practolol, ${ }^{1}$ propranolol hydrochloride, and phentolamine mesylate. Statistical comparisons were made using the $t$ test for paired data (8).

\section{RESULTS}

Effects of practolol on coronary responses to adrenergic stimuli. Intravenous administration of practolol

\footnotetext{
${ }^{1}$ Practolol (AY-21,011) was generously supplied by Ayerst Laboratories, New York.
}

produced small but significant increases in coronary perfusion pressure associated with decreases in LV $\mathrm{dp} / \mathrm{dt}$ without significant changes in heart rate or arterial pressure (Table I).

Before administration of practolol, isoproterenol, sympathetic nerve stimulation, and norepinephrine caused reductions in perfusion pressure accompanied by increases in $\mathrm{LV} \mathrm{dp} / \mathrm{dt}$, heart rate, and systolic pressure (Table II and Figs. 2 and 3). Small transient increases in perfusion pressure often preceded the reductions with nerve stimulation (Fig. 3) and norepinephrine, but not with isoproterenol (Fig. 2).

After administration of practolol, isoproterenol produced reductions in perfusion pressure which were smaller than those observed before practolol, but these occurred without significant increases in $\mathrm{LV} \mathrm{dp} / \mathrm{dt}$, heart rate, and arterial pressure (Table II and Fig. 2). In contrast, practolol reversed the effect of both nerve stimulation (Fig. 3) and norepinephrine from decreases to increases in perfusion pressure (Table II); increases in $\mathrm{dp} / \mathrm{dt}$, heart rate and arterial pressure were reduced or blocked by practolol (Table II).

Glyceryltrinitrate, 3 and $6 \mu \mathrm{g}$, was used as an internal dilator control and produced decreases in perfusion pressure which averaged $26 \pm 2.9$ (SEM) and $32 \pm 2.2$ $\mathrm{mm} \mathrm{Hg}$, respectively, before practolol. Corresponding 
TABLE I

Effect of Intravenous Administration of Practolol (1 $\mathrm{mg} / \mathrm{kg}$ i.v.)

\begin{tabular}{|c|c|c|c|c|c|c|c|c|}
\hline & \multicolumn{2}{|c|}{$\begin{array}{c}\text { Coronary perfusion } \\
\text { pressure }\end{array}$} & \multicolumn{2}{|c|}{$\begin{array}{l}\text { Systolic/diastolic } \\
\text { pressure }\end{array}$} & \multicolumn{2}{|c|}{ Heart rate } & \multicolumn{2}{|c|}{$L V d p / d t$} \\
\hline & Before & After & Before & After & Before & After & Before & After \\
\hline & \multicolumn{2}{|c|}{$m m \mathrm{Hg}$} & \multicolumn{2}{|c|}{$m m \mathrm{Hg}$} & \multicolumn{2}{|c|}{ beats $/ \min$} & \multicolumn{2}{|c|}{$m m \mathrm{Hg} / \mathrm{sec}$} \\
\hline Mean & 135 & 146 & $129 / 94$ & $126 / 93$ & 133 & 128 & 3479 & 2859 \\
\hline SEM & 8.7 & 9.0 & $5.1 / 4.4$ & $4.7 / 4.6$ & 9.9 & 9.2 & 325 & 226 \\
\hline $\mathrm{n}$ & 22 & 22 & 21 & 21 & 9 & 9 & 16 & 1 \\
\hline$P$ values & \multicolumn{2}{|c|}{$<0.01$} & \multicolumn{2}{|c|}{$>0.05^{*}$} & \multicolumn{2}{|c|}{$>0.05$} & \multicolumn{2}{|c|}{$<0.01$} \\
\hline
\end{tabular}

${ }^{*} P>0.05$ for both systolic and diastolic pressures.

values after practolol were not significantly different and averaged $19 \pm 1.7$ and $27 \pm 2.6 \mathrm{~mm} \mathrm{Hg}$, respectively. These responses occurred without changes in arterial pressure, heart rate, or $\mathrm{LV} \mathrm{dp} / \mathrm{dt}$.

Effects of propranolol after practolol. Propranolol blocked completely the decreases in perfusion pressure caused by isoproterenol (Table III). The increases in perfusion pressure seen in response to nerve stimulation and norepinephrine after practolol were not augmented by propranolol (Table III). Angiotensin, $0.25 \mu \mathrm{g}$, used as an internal constrictor control, produced increases in perfusion pressure averaging $28 \pm 5.9 \mathrm{~mm} \mathrm{Hg}$ after practolol and $25 \pm 9.4 \mathrm{~mm} \mathrm{Hg}$ after subsequent administration of propranolol.
Effects of phentolamine after practolol. The constrictor responses to nerve stimulation and norepinephrine after practolol were reduced and reversed, respectively, by intracoronary administration of phentolamine, $1 \mathrm{mg}$ (Fig. 4). Responses to angiotensin were not altered (Fig. 4).

Responses in hind paw. The dilator responses to isoproterenol and glyceryltrinitrate were not altered by practolol (Fig. 5).

\section{DISCUSSION}

Practolol reduced the coronary response to isoproterenol, but significant dilatation with isoproterenol persisted

TABLE II

Responses to Isoproterenol, Nerve Stimulation, and Norepinephrine before and after Practolol (1 $\mathrm{mg} / \mathrm{kg}$ i.v.) in 13 Dogs

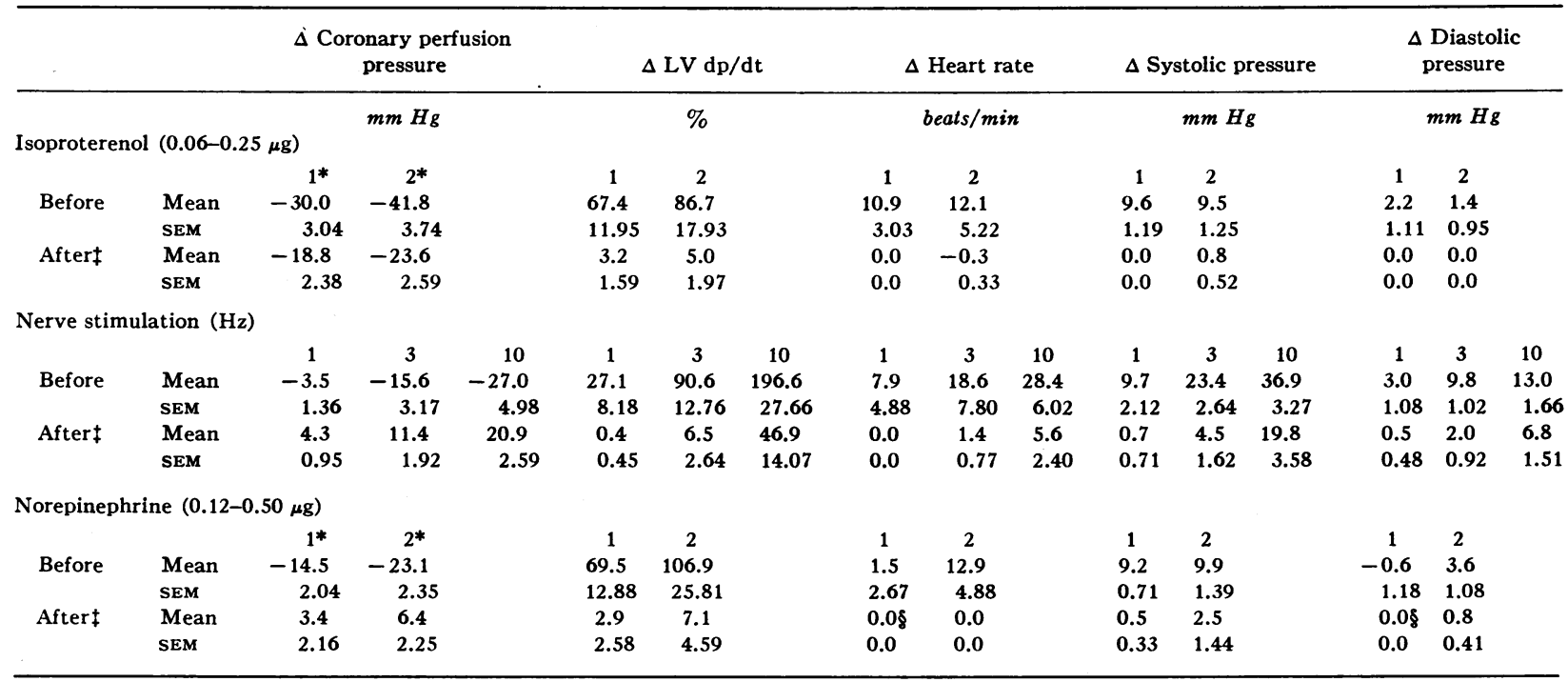

* The numbers 1 and 2 refer to the two doses of isoproterenol and norephinephrine; dose 2 was always twice as large as dose 1 . The interventions were given in random order before and after the blocker.

¥ All responses observed after practolol differed significantly $(P<0.05)$ from those observed before practolol.

\&esponses observed after practolol which did not differ significantly from those observed before practolol. 


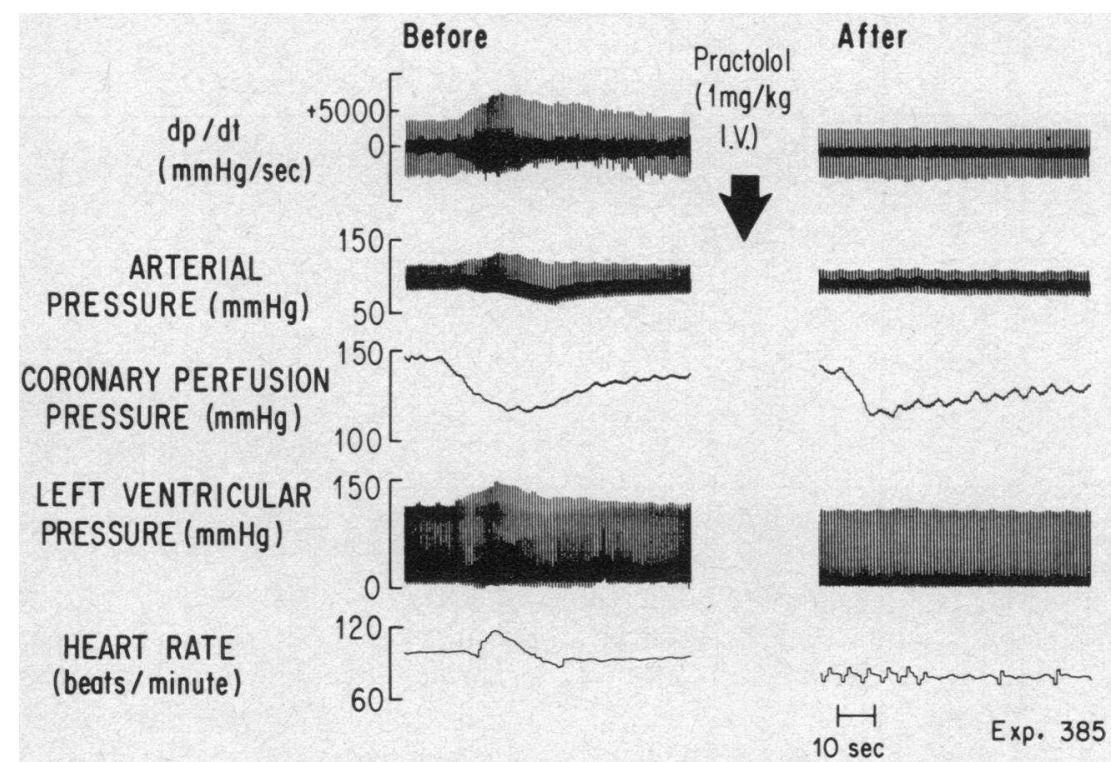

FigLre 2 Responses to isoproterenol $(0.12 \mu \mathrm{g})$ before (left) and after (right) practolol.

even after inhibition of its myocardial effects by practolol. This dilatation was abolished subsequently by blockade of vascular beta receptors with propranolol. We considered three explanations for the reduction in the dilator response to isoproterenol after practolol.

The first was that practolol reduced the response by producing partial blockade of coronary vascular beta receptors. This possibility is remote since we selected a dose of practolol which was too small to block vascular beta receptors, yet sufficient to block the myocardial response to adrenergic stimuli. Dunlap and Shanks found that one $\mathrm{mg} / \mathrm{kg}$ of practolol given locally did not alter the increases in iliac blood flow produced by isoproterenol (7). In the present study we confirmed

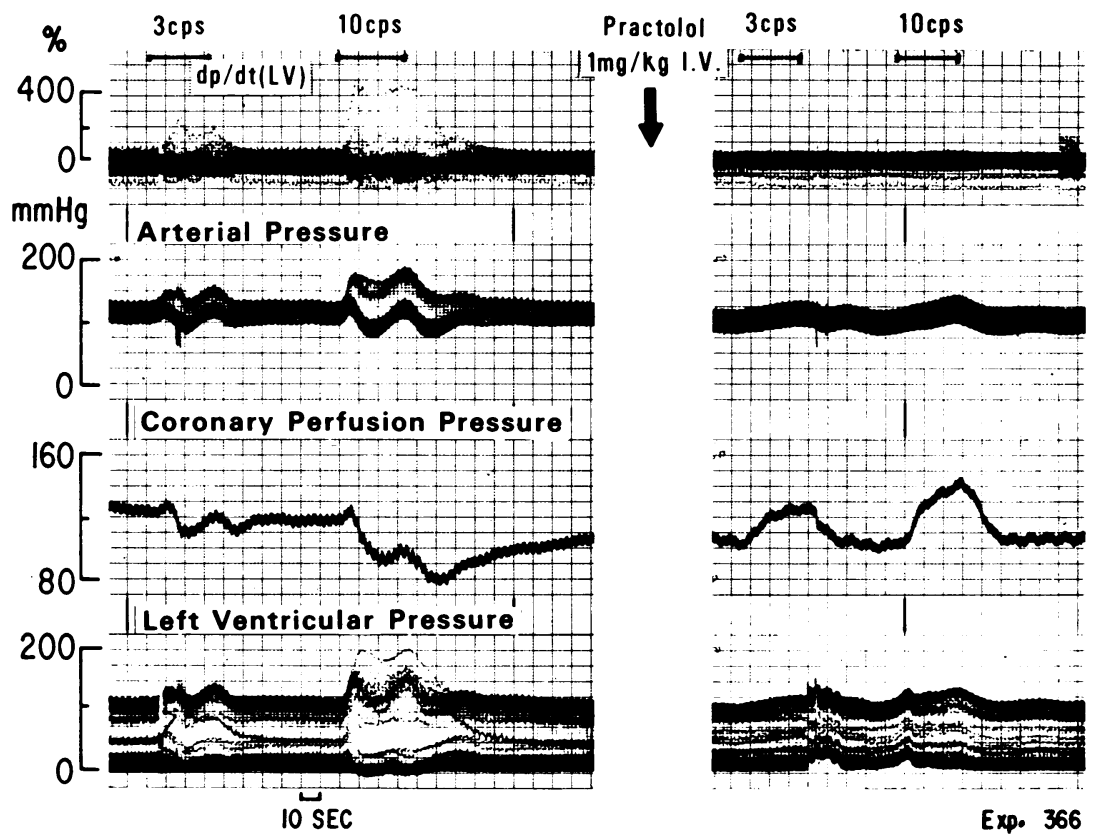

Figure 3 Responses to electrical stimulation of left cardiac sympathetic nerves at 3 and $10 \mathrm{~Hz}$ before (left) and after (right) practolol. 
the ineffectiveness of this dose of practolol in blocking vascular beta receptors in the hind paw. It is possible that much larger doses of practolol would block vascular beta receptors in the coronary as well as other vessels $(7,9)$ just as propranolol did in this study. We did not administer larger doses of practolol because our aim was not to study the action of practolol at various dose levels but rather to use this drug as a pharmacologic tool to separate the changes in coronary resistance which reflect indirect myocardial effects from those which represent direct vascular effects.

The second possibility was that the decreased dilator responses after practolol resulted from inhibition of the myocardial effects of isoproterenol. This explanation seemed more likely because results of other investigators $(2,4)$ and the present experiments indicate that increases in myocardial contractility and metabolism resulting from administration or release of norepinephrine produce coronary vasodilatation which is reversed after blockade or partial suppression of the myocardial response.

The third explanation may be that the reduction in responsiveness may be nonspecific. The use of the internal control, glyceryl trinitrate, allowed us to estimate the nonspecific effect of practolol or any other uncontrolled variable on coronary vasodilatation and
CHANGES in CORONARY RESISTANCE AFTER PRACTOLOL ONLY 표 AND AFTER PRACTOLOL + PHENTOLAMINE

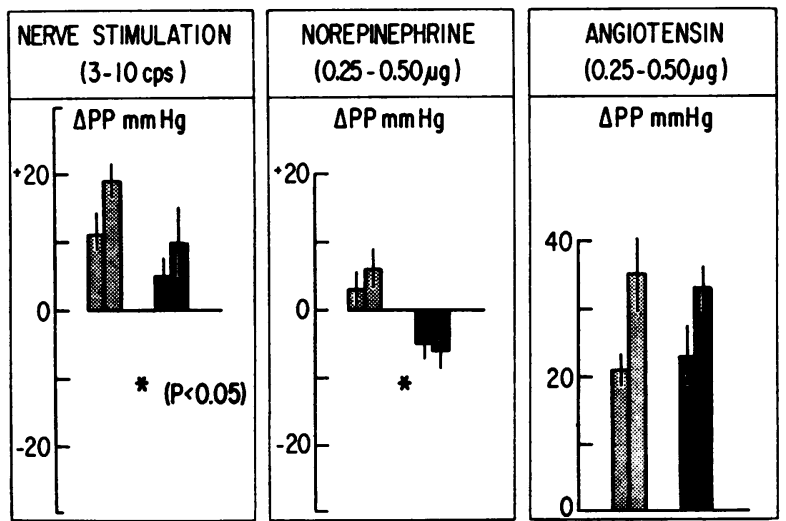

Figure 4 Entries are mean changes in perfusion pressure (PP) \pm SEM from seven experiments.

that effect was small. Taking into consideration the slight reduction of the coronary dilator action of glyceryltrinitrate after practolol, approximately $70 \%$ of the coronary dilator effect of isoproterenol remained after blockade of its myocardial effects. We conclude that the coronary vasodilator response to isoproterenol

TABLE III

Comparison of Responses after Practolol ( $1 \mathrm{mg} / \mathrm{kg}$ i.v.) Only with Responses after Practolol plus Propranolol (0.2 mg/kg i.v.) in Seven Dogs

\begin{tabular}{|c|c|c|c|c|c|c|c|}
\hline & & \multicolumn{3}{|c|}{$\Delta$ Perfusion pressure } & \multicolumn{3}{|c|}{$\Delta \mathrm{LV} \mathrm{dp} / \mathrm{dt}$} \\
\hline & & & $m m \mathrm{Hg}_{\mathrm{g}}$ & & & $\%$ & \\
\hline \multicolumn{8}{|l|}{ Isoproterenol $(0.06-0.25 \mu \mathrm{g})$} \\
\hline & & 1 & 2 & & 1 & 2 & \\
\hline \multirow{2}{*}{ After practolol } & Mean & -18.7 & -23.0 & & 0.0 & 2.8 & \\
\hline & SEM & 4.40 & 5.00 & & 0.0 & 2.80 & \\
\hline \multirow[t]{2}{*}{ After practolol and propranolol } & Mean & -0.3 & -2.0 & & 0.0 & 0.0 & \\
\hline & SEM & 0.33 & 1.26 & & 0.0 & 0.0 & \\
\hline$P$ values & & $<0.01$ & $<0.01$ & & $>0.05$ & $>0.05$ & \\
\hline \multicolumn{8}{|l|}{ Nerve Stimulation $(1-10 \mathrm{~Hz})$} \\
\hline & & .1 & 3 & 10 & 1 & 3 & 10 \\
\hline \multirow[t]{2}{*}{ After practolol } & Mean & 4.3 & 11.7 & 25.0 & 0.0 & 8.6 & 39.8 \\
\hline & SEM & 2.24 & 3.58 & 5.98 & 0.0 & 6.22 & 20.45 \\
\hline \multirow[t]{2}{*}{ After practolol and propranolol } & Mean & 4.6 & 8.3 & 15.5 & 0.0 & 2.9 & 2.3 \\
\hline & SEM & 2.38 & 4.50 & 8.22 & 0.0 & 2.86 & 2.33 \\
\hline$P$ values & & $>0.05$ & $>0.05$ & $>0.05$ & $>0.05$ & $>0.05$ & $>0.05$ \\
\hline \multicolumn{8}{|l|}{ Norepinephrine $(0.25-0.50 \mu \mathrm{g})$} \\
\hline & & 1 & 2 & & 1 & 2 & \\
\hline \multirow[t]{2}{*}{ After practolol } & Mean & 6.9 & 9.4 & & 0.0 & 1.8 & \\
\hline & SEM & 1.50 & 2.17 & & 0.0 & 1.79 & \\
\hline \multirow{2}{*}{ After practolol and propranolol } & Mean & 5.1 & 6.9 & & 0.0 & 0.0 & \\
\hline & SEM & 2.04 & 2.82 & & 0.0 & 0.0 & \\
\hline$P$ values & & $>0.05$ & $>0.05$ & & $>0.05$ & $>0.05$ & \\
\hline
\end{tabular}

See legend for Table II. 


\section{CHANGES in RESISTANCE in HIND PAW BEFORE AND AFTER PRACTOLOL}
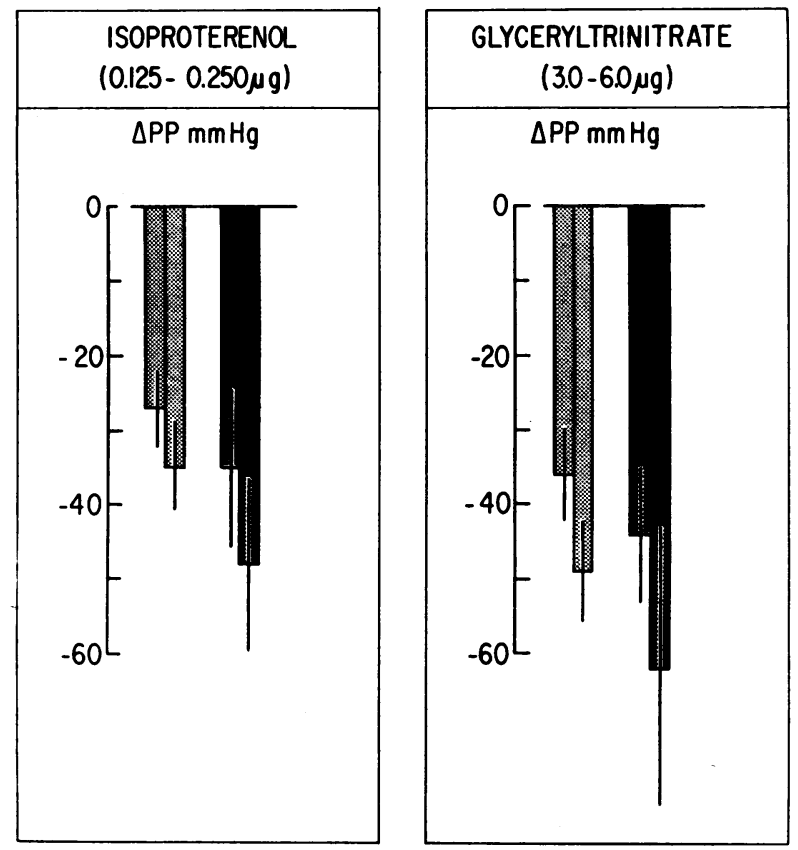

FIGURE 5 Entries are mean values ISEM from $10 \mathrm{ex}-$ periments.

is both direct and indirect, resulting from stimulation of vascular and myocardial beta receptors, with the direct vascular effect predominating in this study. Earlier studies of coronary reactivity in arrested hearts (3) or isolated vessels (6) demonstrated that isoproterenol activates beta receptors in these vessels. The present experiments in the beating heart support and these and other more recent observations (9). The recent findings of Ross and Jorgensen (9) also would support the conclusion that the coronary dilator action of isoproterenol is predominantly the result of a direct vascular effect.

In contrast with isoproterenol, the coronary dilator response to norepinephrine and nerve stimulation is an indirect effect resulting from stimulation of beta receptors in the myocardium; the direct effect on coronary vessels is vasoconstriction which is minimal compared with that seen with the same stimuli in other vascular beds (10). Administration of phentolamine, an alpha receptor blocking agent, reduced the constriction with nerve stimulation and reversed the response to norepinephrine from constriction to slight dilatation. The effect of angiotensin used as an internal control was not altered by phentolamine. We considered the possibility that constrictor responses to norepinephrine and nerve stimulation seen after practolol resulted from residual increases in left ventricular pressure and wall tension, but this seemed unlikely since these responses often occurred without such increases and were blocked by phentolamine. We did not attempt to block the slight dilator response which was seen with norepinephrine after practolol and phentolamine. Instead, we tried to determine if norepinephrine and nerve stimulation produced significant stimulation of coronary vascular beta receptors by comparing responses after practolol alone with responses after practolol plus propranolol. Addition of propranolol did not augment the constriction suggesting that vascular beta receptors do not play an important role in the coronary responses to nerve stimulation or norepinephine.

\section{ACKNOWLEDGMENTS}

This study was supported by research grants from the American and Iowa Heart Associations, and from the U. S. Public Health Service (HE-09835 and HE-02644); by a Clinical Cardiology Traineeship 5T-12HE-05729 (Dr. McRaven) and a Research Career Program Award HE-K317013 (Dr. Abboud) from the U. S. Public Health Service; and by a Research and Education Associateship (Dr. Mark) from the Veterans Administration.

\section{REFERENCES}

1. McRaven, D. R., F. M. Abboud, A. L. Mark, and H. E. Mayer. 1970. Responses of coronary vessels to adrenergic stimuli. Clin. Res. 18: 320.

2. Berne, R. M. 1964. Regulation of coronary blood flow. Physiol. Rev. 44: 1 .

3. Klocke, F. J., G. A. Kaiser, J. Ross, Jr., and E. Braunwald. 1965. An intrinsic adrenergic vasodilator mechanism in the coronary vascular bed of the dog. Circ. Res. 16: 376 .

4. Berne, R. M. 1958. Effect of epinephrine and norepinephrine on coronary circulation. Circ. Res. 6: 644.

5. Hardin, R. A., J. B. Scott, and F. J. Haddy. 1961. Effect of epinephrine and norepinephrine on coronary vascular resistance in dogs. Amer. J. Physiol. 201: 276.

6. Zuberbuhler, R. C., and D. F. Bohr. 1965. Responses of coronary smooth muscle to matecholamines. Circ. Res. 16: 431 .

7. Dunlop, D., and R. G. Shanks. 1968. Selective blockade of adrenoceptive beta receptors in the heart. Brit. J. Pharmacol. Chemother. 32: 201.

8. Snedecor, G. W., and W. G. Cochran. 1956. Statistical Methods. Iowa State University Press, Ames, Iowa. 5th edition. 46.

9. Ross, G., and C. R. Jorgensen. 1970. Effects of a cardioselective beta-adrenergic blocking agent on the heart and coronary circulation. Cardiovasc. Res. 4: 148.

10. Abdel-Sayed, W. A., F. M. Abboud, and D. R. Ballard. 1970. Contribution of venous resistance to total vascular resistance in skeletal muscle. Amer. J. Physiol. 218: 1291. 